\title{
Understanding the Prevalence of Police Torture and Assault in Kwazulu-Natal Province, South Africa
}

\author{
Philisiwe Nicole Hadebe \\ University of KwaZulu-Natal
}

\begin{abstract}
Section 49 of the Criminal Procedure Act, 51 of 1977 (as amended) permits the police to use "reasonable necessary and proportional" force to effect an arrest. This license has been met with criticism as the police have continued to informally use the operational methods of torture and assault in the execution of their duties in the reformed police service of South Africa in the post-apartheid era. According to the Independent Police Investigative Directorate (IPID) annual reports, from 2012 2019 approximately 27668 cases of torture and assault have been reported with only 162 cases closed with a criminal conviction and 770 disciplinary convictions. To understand the cause of such an influx of cases of police torture and assault, the study explored the organizations and situational factors that contribute to police torture and assault and extended the focus to identifying the challenges experienced by IPID in investigating cases of torture and assault which have led to low prosecution and conviction rate. The study adopted a qualitative approach and interviewed ten IPID investigating officers. The findings revealed that pressure on police officers to meet projected targets for firearms or drug retrieval lead to police officers assaulting and torturing citizen when they resist an arrest, refuse to cooperate and/or question police procedures. Furthermore, due to IPID lacking resources and power; complainants failing to produce evidence; and lack of cooperation from complainants, police officers, and station commanders, IPID investigating officers produce poor quality dockets which leads to a low rate of prosecution and conviction.
\end{abstract}

Keywords: Arrest; Conviction rate; Independent Police Investigative Directorate; South African Police Service; Prosecution 